\title{
EXPERIMENTAL AND ANALYTICAL STUDY OF DELAYED FRACTURE IN HIGH STRENGTH BOLTS
}

\author{
高力ボルトの遅れ破壊に関する実験および解析的研究
}

\author{
Hagai SHIMOMURA* and Takeshi SHINODA** \\ 下村波基，篠田 剛
}

\begin{abstract}
Delayed fracture tests with cathodically pre-charged specimens were performed measuring acoustic emission ( $A E$ ). Experimental parameters were ratio of axial force to design bolt axial force, cathodically hydrogen charged time and effect of heat treatment. It was observed that time to fracture was somewhat affected by charged time and axial force ratio.

Analytical process of diffusible hydrogen around a thread root and a tip of notch was compared with experimental one by $\mathrm{AE}$ signal and branching phenomenon near crack tip, and resulted in a good agreement.
\end{abstract}

Keywords : delayed fracture, high-strength bolt, hydrogen induced crack, finite element method, diffusion

遅れ破壊, 高力ボルト，水素誘起割れ，有限要素法，拡散

\section{Introduction}

The present trend for taller buildings and greater spans has led to $590 \mathrm{MPa}$ tensile strength class or higher classes of high strength steels being considered for use in building construction. Unlike in the case of mild steel, a shortage of the ability of a stress re-distribution due to a higher yield ratio won't show the sufficient load-carrying capacity of frames after reaching mechanism. Horizontal load-carrying capacity of frames depends much on connections such as beam to column connection or bracings which are jointed by welding or bolt. In the case of bolted joints bolt holes reduce the sectional area of a base metal so that a stress concentration becomes higher around bolt holes, and consequently the yielding and deterioration occur much earlier than they are expected to.

The loss of sectional area of base metal due to bolt holes must be smaller as far as possible to promote a sound stress re-distribution around bolt holes, and it is necessary that the strength of a high-strength bolt must become higher to reduce the loss of section, and also to insure the load-carrying capacity and deformability of bolted joints. But strengthening of high strength bolts has much possibility of a delayed fracture as reported.

Many studies about hydrogen induced cracking (HIC) in high strength weld metals or high tension steels under stress have been widely reported [3-10]. Mathematical efforts considering the distribution of stress field were done to explain the phenomenon of hydrogen embrittlement ahead of cracks where stress concentrates [2].

A delayed failure of the high tension bolts has been reported since they had been widely introduced into steel structures and bridges. Most of these failures have been thought to be induced by diffusible hydrogen because these failures often occurred under the environmental circumstances seaside or industrial areas that promote corrosion and hydrogen charging [11]. Although many studies about HIC

\footnotetext{
*.岐阜工業高等専門学校 助教授・工博

** 名古屋大学工学部材料プロセス工学科 講師・工博
}

Assoc. Prof., Dept. of Architecture Gifu National College of Technology, Dr. Eng.

Lecturer, Faculty of Engineering Nagoya Univ., Dr. Eng. 
have been performed, behavior of diffusible hydrogen in high tension bolts which have a geometrical notch, i. e., a root of thread, has not yet been solved satisfactorily due to the complexity of many problems about HIC. The analytical solution needs to account for not only the gradient of hydrogen concentration but also the stress distribution in order to solve the diffusional process of hydrogen in high tension bolts under stress.

\section{Nomenclature}

$D$ : hydrogen diffusivity

$\sigma:$ hydrostatic component of stress tensor or applied stress on the axial section

$\sigma_{s}:$ standard bolt stress of $\mathrm{F} 13 \mathrm{~T}$ bolt

$J$ : hydrogen flux

$\gamma:$ activity; chemical potential in the standard state

$C$ : hydrogen concentration

$T:$ absolute temperature

$R:$ gas constant

$t:$ time

$V H:$ specific molar volume of hydrogen atoms

\section{Mathematical Development and Discretization}

\section{Diffusive Process of Hydrogen Dependent on Stress Gradinet and Discretization for Numeric} Analysis Finite Element Method (FEM)

Consider a cubic element $\mathrm{dv}$ in arbitrary location $(x, y, z)$ as shown in Fig. 1 and time $t$ in some body; hydrogen concentration can be defined as $\mathrm{C}(x, y, z, t)$. Volume of hydrogen accumulated in its cubic element can be expressed by Fourier's law and the variation of concentration with time $t$ can be written as,

$$
\frac{\partial c}{\partial t}=\frac{\partial}{\partial x}\left(D_{x} \cdot \frac{\partial c}{\partial x}\right)+\frac{\partial}{\partial y}\left(D_{y} \frac{\partial c}{\partial y}\right)+\frac{\partial}{\partial z}\left(D_{z} \frac{\partial c}{\partial z}\right)=D \nabla^{2} c
$$

In the case of diffusion of hydrogen atoms in steel subjected to stress, from Fick's first law, the flow vector $\mathrm{J}$ of the atoms diffusing through unit area per unit time at any point in the material can be expressed as follows

$$
J=-D C\left(\frac{\nabla C}{C}+\frac{\nabla \gamma}{\gamma}-\frac{V H}{R T} \nabla \sigma\right)
$$

Also, from Fick's second law

$$
\begin{aligned}
\frac{\partial c}{\partial t} & =-\nabla J \\
& =D \nabla^{2} C+\nabla\left(\frac{D}{\gamma} C \nabla \gamma\right)-\frac{D V H}{R T}\left(\nabla C \nabla \sigma+C \nabla^{2} \sigma\right)
\end{aligned}
$$

Assuming the activity $\gamma$ is constant all over the object and the stress is a single-valued and continuous function under analysis, $\nabla \gamma, \nabla^{2} \sigma$ and in the second and third terms of equation ( 3 ) respectively can be considered to be zero so that the variation of hydrogen concentration with time can thus be independent of the activity $\gamma$ and expressed as a function of the hydrogen concentration and the stress

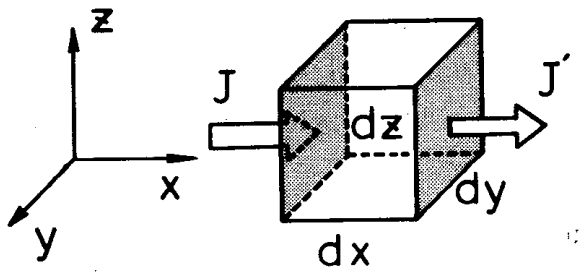

Fig. 1 Hydrogen flux in cubic element gradient.

Let us next consider the application of numerical analysis to this result using FEM. The object to be analyzed is divided into finite, triangular elements, and, using the nodal concentration $\phi$, the hydrogen concentration $C$ within an element at any time $t$ is defined by, 


$$
C(x, y, z, t)=[N(x, y, z) \cdot \phi(t)]
$$

Here, $[N]$ is the interpolation function matrix. When $[N]$ itself is taken as the weighting function, the following equation is obtained using Galerkin's method which is one of weighted residual methods :

$$
\int_{v_{e}}[N]^{T}\left\{-\frac{\partial c}{\partial t}+D \nabla^{2} C-\frac{D V H}{R T} \nabla C \nabla \sigma\right\} d V=0
$$

where $V_{e}$ expresses the elemental volume.

Using Green's theorem and some boundary conditions, considered as a two-dimensional problem, equation ( 5 ) yields for a single triangular element :

$$
[k]\{\phi\}+[m]\left\{\frac{\partial \phi}{\partial t}\right\}=\{f\}
$$

where,

$$
[k]=[k d]+[k s]+[k c]
$$

$[k d]$ : hydrogen diffusion matrix of an element

$[k s]$ : stress dependent hydrogen conductivity matrix

$[k c]$ : concentration dependent hydrogen conductivity matrix

$[m]$ : hydrogen capacity matrix

$\{f\}$ : hydrogen flux vector

For the entire object under analysis,

$$
[K]\{\Phi(t)\}+[M]\left\{\frac{\partial \Phi(t)}{\partial t}\right\}=\{F\}
$$

Using this equation, the object under analysis can be expressed in a form of discretization of 2-dimensional space regions. And discretization of time regions also becomes possible with this diffusion equation by employing Crank-Nicolson's finite difference method. Therefore, using these two discrete techniques, it becomes possible to solve the unsteady state problem involving hydrogen diffusion in steel of a given geometric shape.

\section{Experiments}

\subsection{Delayed Fracture Test Specimen}

$\mathrm{F} 10 \mathrm{~T}$ high-strength bolt ( $\mathrm{F} 10 \mathrm{~T}$ bolt) is widely used in steel structures and bridges as a friction bolt. F $13 \mathrm{~T}$ high-strength bolt ( $\mathrm{F} 13 \mathrm{~T}$ bolt), which is higher-strength bolt than F $10 \mathrm{~T}$ bolt and whose standard tensile strength is over $1275 \mathrm{MPa}$, had been used for a while, but now prohibited by Japan Industrial Standard because of the occurrence of delayed fracture as it had been reported [8]. An actual F $10 \mathrm{~T}$ bolt was only quenched and tempered in usual manner to get F $13 \mathrm{~T}$ bolt. Its features are that Boron is contained to improve the hardenability and thread is rolled hot. Its chemical composition and mechanical properties are shown in Table 1.

The mechanical saw notch, whose width and depth was 0.2 and $1.0 \mathrm{~mm}$ respectively, was inserted to promote the fracture at the imperfect root of the thread where screw cutting starts and also a stress concentration is higher than the axial part.

\section{2 Pre-charging Condition}

These specimens were pre-charged cathodically in $2 \% \mathrm{H}_{2} \mathrm{SO}_{4}$ electrolyte for 1 or 2 hours with about $0.5 \mathrm{~A} . / \mathrm{cm}^{2}$ current density at room temperature. They were shielded with a sealing material to be charged locally around the notch and imperfect root of a thread.

The charging system is illustrated in Fig. 2. While charging, bubbles generated actively on both

Table 1 Chemical composition and mechanical properties of F $13 \mathrm{~T}$ high-strength bolt steel Chemical Composition ( WT $\%$ )

\begin{tabular}{ccccccccc}
\hline $\mathrm{C}$ & $\mathrm{Si}$ & $\mathrm{Mn}$ & $\mathrm{P}$ & $\mathrm{S}$ & $\mathrm{Cu}$ & $\mathrm{Ni}$ & $\mathrm{Cr}$ & $\mathrm{B}$ \\
\hline 0.34 & 0.22 & 1.27 & 0.024 & 0.018 & 0.01 & 0.02 & 0.03 & 0.0017 \\
\hline
\end{tabular}

\begin{tabular}{ccc}
\multicolumn{3}{c}{ Mechanical Properties ( MPa ) } \\
\hline & Yield strength & Tensile Strength \\
\hline F13T Bolt & 1294.5 & 1363.1 \\
\hline
\end{tabular}




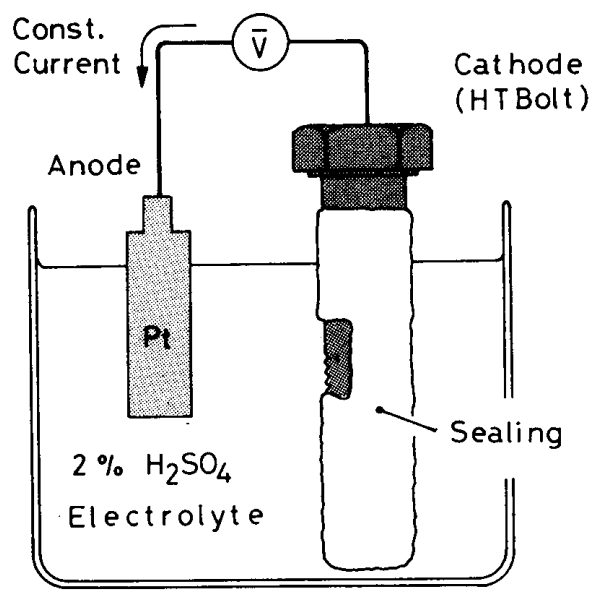

Fig. 2 Schematic diagram of the hydrogen charging set-up

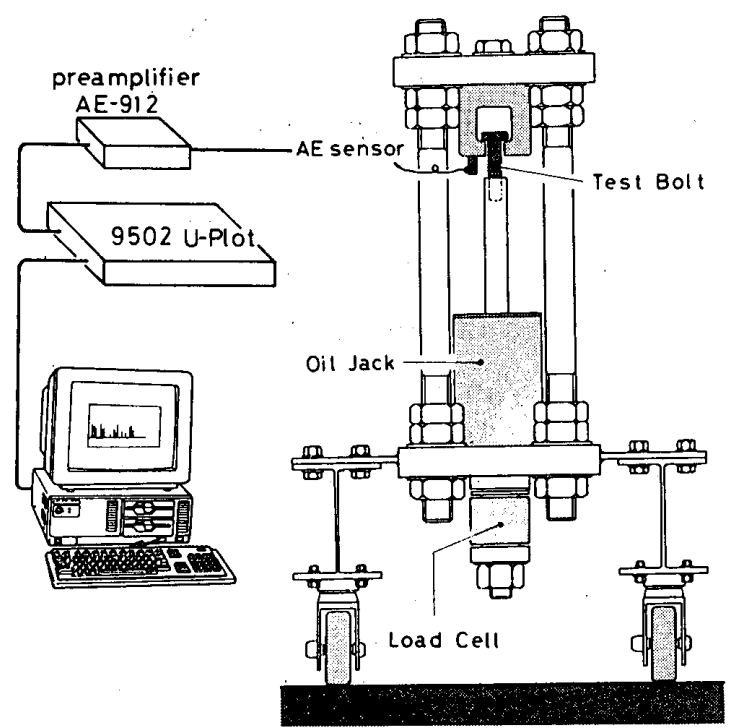

Fig. 3 Diagram of the loading system with $\mathrm{AE}$ measuring equipment

surfaces of electrodes, but direct current was kept constant by a regulated power supply.

\section{3 Loading and Measuring System of Acoustic Emission}

Pre-charged specimens were set up into the loading system as soon as possible to prevent diffusible hydrogen from being dismissed into the atmosphere. The loading system consists of a 50 ton oil jack, reaction beams and equipments of acoustic emission ( $\mathrm{AE}$ ) system as it is illustrated in Fig. 3.

$\mathrm{AE}$ sensor was fixed by spring at this supporting jig, AE signal was measured through this jig indirectly, and then stored in the micro-computer at regular intervals. Specimens were tightened and stressed after hydrogen charging with each aimed constant load less than a standard design stress level that is about $65 \%$ of each yield strength.

\subsection{Process till Failure and Test Results}

The initiation and propagation of a crack was indirectly observed through frequency of AE events, $A E$ sensor was kept on the same place, and AE signals over 90 deci Bel were counted until the specimen was fractured or AE signals were not observed any more. When stress level was higher, AE signal occurred as soon as it was tightened, and was continuously counted until fracture. On the other hand, when short charged or lower stressed, AE events didn't occur soon and they were observed intermittently until fracture.

Figure 4 shows examples of series of deci Bel, lapse time after loading, and AE events. Specimen No. 13-16 and No.13-18 were in the same stress level with pre-charged 2 and 1 hours respectively. Specimen No.13-16, long-charged specimen, showed continuous and intense AE events from the beginning, and then fractured much earlier than the short-charged specimen No.13-18. Specimen No. 13-19 was, at first, tightened in such a low stress level (50\%) that any AE event didn't occur for about 2 hours. After stressed up to $62.5 \%$ level, AE event then appeared intensely and continuously for about 10 hours, and after all this bolt fractured in about 17 hours.

Test results were plotted in Fig. 5. Delayed fracture occurred only in F $13 \mathrm{~T}$ bolts. This figure shows the relationship between applied stress level and time to fracture. This stress level is normalized by standard design bolt stress demanded for this F $13 \mathrm{~T}$ bolt. Most of specimens were fractured even in the case of a $60 \%$ stress level against the standard design stress level. In this test program fracture was promoted by notch and hydrogen charging so that test specimens which took over about 120 hours to fracture were intentionally finished loading even if there had some possibility of fracture in holding the load. These unloaded bolts are plotted with arrow mark in this same figure.

It can be seen from this figure that there seems to have some tendency that the time to fracture is 

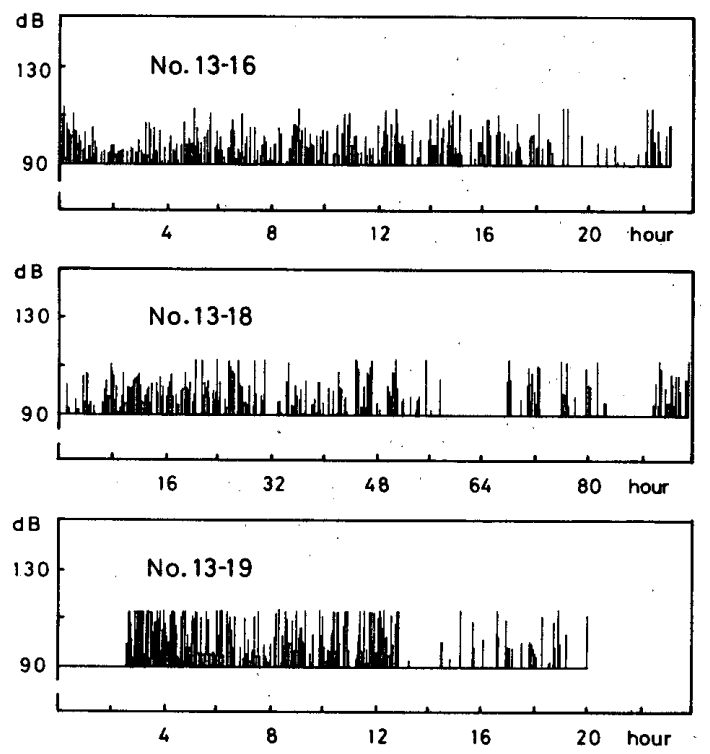

Fig. 4 Records of AE event until fracture

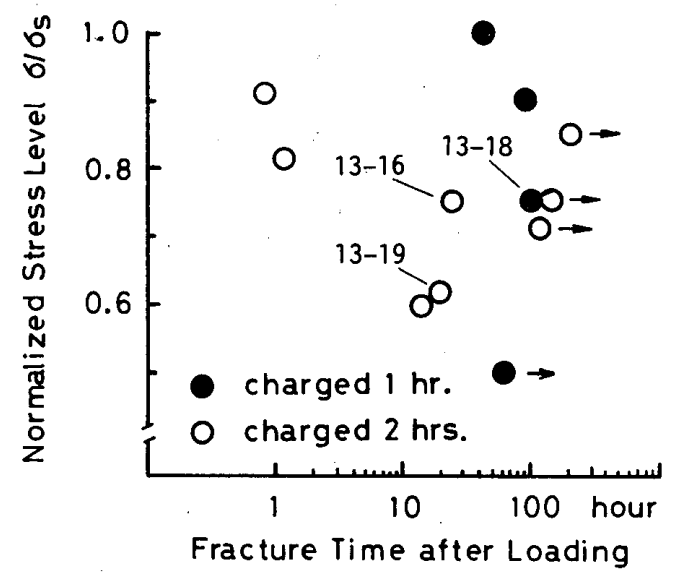

Fig. 5 Fracture time against stress level: stress is normalized by standard design bolt stress

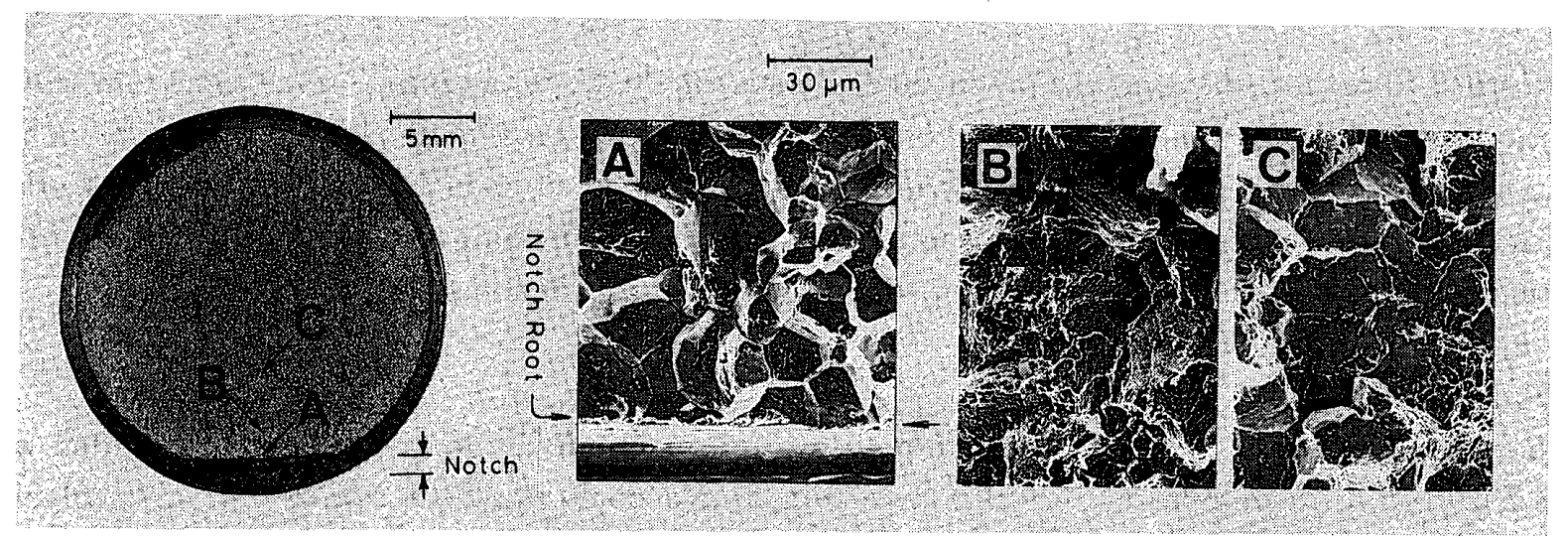

Fig. 6 General view of fracture surface and SEM observation : photo A shows intergranular and transgranular brittle fracture, and quasi-cleavage or ductile fracture can be seen in photo $\mathrm{B}$ and $\mathrm{C}$

somewhat related to both charging time and applied stress. These facts reveal that the quantity of a diffusible hydrogen is in proportion to charging time and also this charged hydrogen is effective and influential in assisting the initiation and propagation of crack in this high-strength bolt whose strength is over $1300 \mathrm{MPa}$.

On the contrary, both notched F $13 \mathrm{~T}$ specimen without hydrogen charging and notched F $10 \mathrm{~T}$ specimen with 2 hours hydrogen charging were also tried under standard design bolt stress level, but neither bolt showed any AE events while loading. These results show that $\mathrm{F} 13 \mathrm{~T}$ bolts used in this experiment have sufficient resistant ability for crack initiation if it were not for any assistance of hydrogen, and also show that ductility or low crack sensitivity, as F $10 \mathrm{~T}$ bolt showed, could arrest the initiation and propagation of crack caused by the hydrogen embrittlement.

\subsection{Fractography}

General views of fracture surface and SEM photos are shown in Fig. 6. These figures indicate that cracks initiated at the mechanical saw notch in each specimen and propagated in a brittle manner in a plane strain field, and that intergranular and transgranular brittle fracture can be seen ahead of the notch. Getting apart from the notch root, quasi-cleavage fracture also can be observed accompanied with the plastic deformation.

View of Micro section perpendicular to fracture surface around notch root, Fig. 7, also shows that fracture path propagates along or across the grain boundary. This figure also shows the branching of the crack. It is considered that the crack initiated ahead of notch happened to branch in two directions 


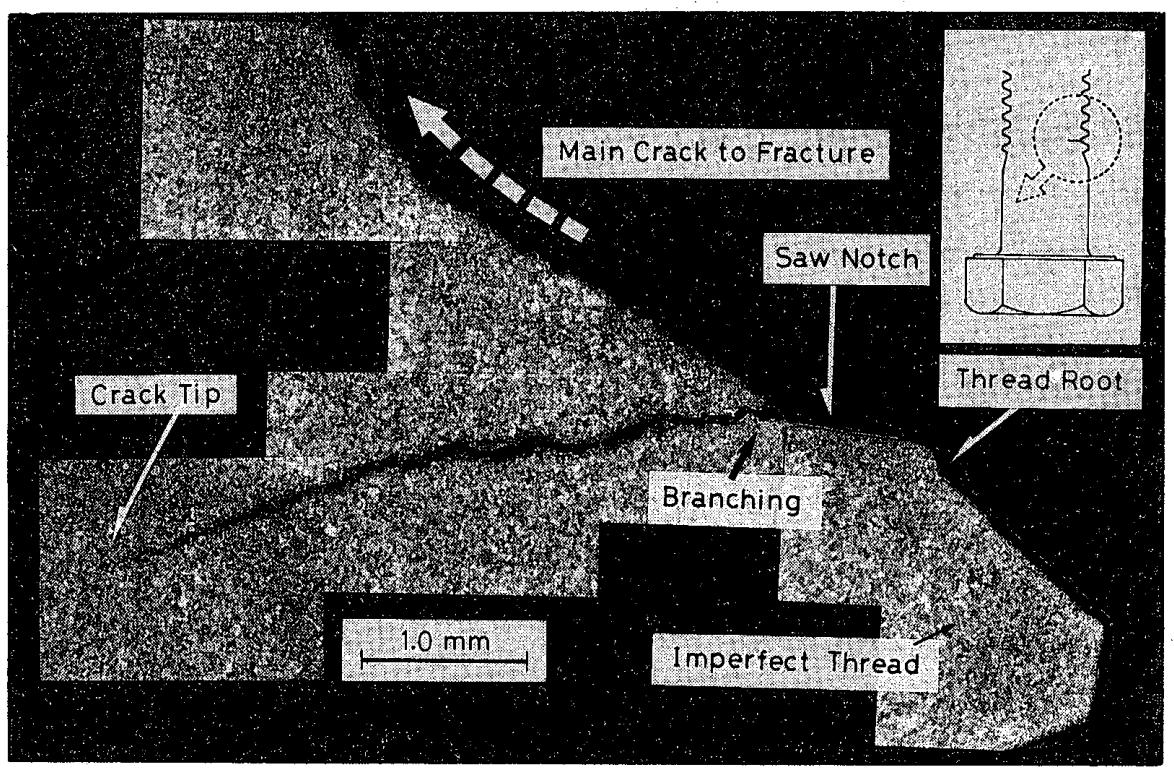

Fig. 7 Macro-section of fracture surface around notch root

where stress is higher, these cracks propagated, dismissing hydrogen into air, at the same rate in each direction for a while, and then only one of cracks led to fracture. This figure shows a typical branching phenomenon at the tip of saw notch. Some branchings appeared soon like this figure, and others occurred after propagating in the same direction of notch. But most of all specimens, took a longer time to fracture or not led to fracture, indicated these branching phenomena.

\section{Analytical Results}

Numerical analysis of the unsteady state process of diffusible hydrogen in metal was executed with FEM based on the development of Fick's laws and taking account of the stress field. In this analysis a bolt could be treated as a two-dimensional problem that is a plane plate with a unit thickness $(1 \mathrm{~cm})$. The proportion of width to thickness in the analytical section is almost the same so that the analytical results solved by FEM as a plane strain problem would give almost same results as obtained in an actual bolt. Based on this mechanical assumption, and considered a restraint by the nut, division around thread into triangular elements is shown in Fig. 8.

It may be natural that hydrogen diffusivity is affected by the micro structure. In the case of this
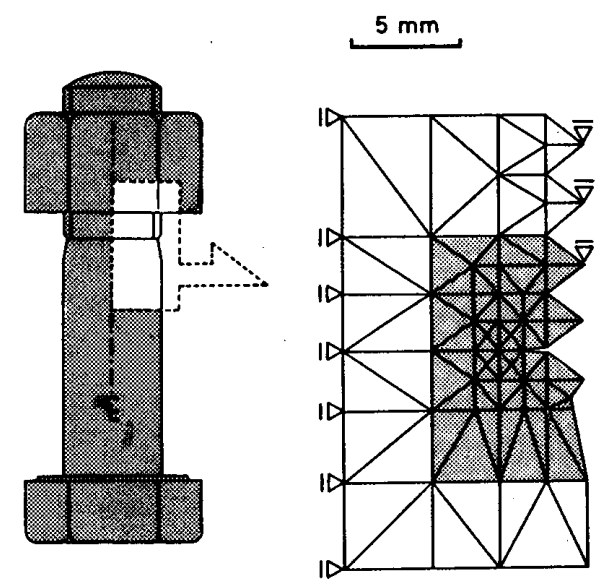

Fig. 8 Division of a bolt-nut under stress into triangular elements: shaded area in division is used for illustration of diffusional process of hydrogen in the next figure high-strength bolt, the micro structure and grain size is changing, showing layers, from surface to center due to manufacturing process like a hot rolling and heat treatment. But these layers are very thin and gradually changed so that it can be considered that hydrogen diffusivity is uniform under analytical object.

Assuming a standard design bolt stress and an initial permeation of hydrogen by this hydrogen charging system, equivalent nodal loads and nodal hydrogen concentration were introduced. After elemental stresses were solved under these conditions, matrix [ $k s]$ could be obtained as it is done in matrix $[k d]$ or $[k c]$, assuming that the stress gradient between elements could be expressed as nodal stress. This nodal stress is defined by taking average of 


\section{$\square \square \square$ Normalized Density}

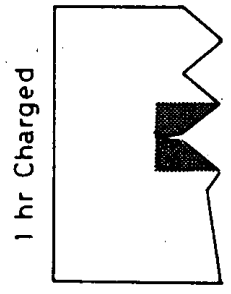

Initial State

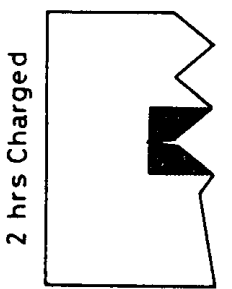

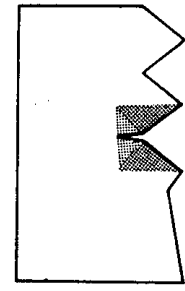

$t=20$

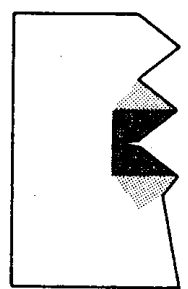

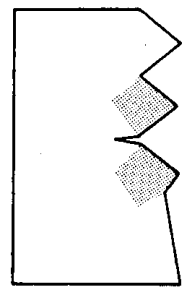

$t=50$

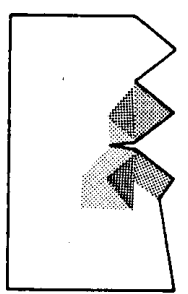

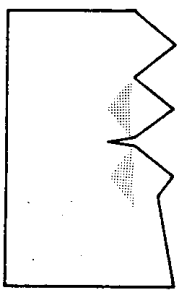

$t=300$

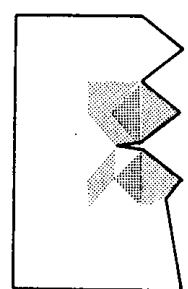

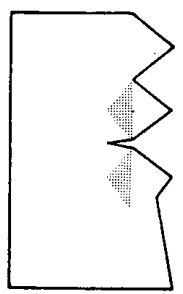

$t=500 \mathrm{~min}$

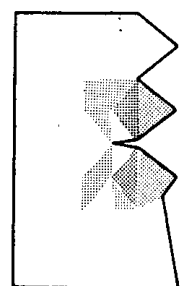

Fig. 9 Analytical diffusional process of hydrogen near imperfect root of thread with notch

elemental stresses in each element where the node is held in common. The initial stage of hydrogen diffusional process, i.e., initial permeation, was illustrated in the initial state of Fig. 9.

Values for computational analysis used here are ; hydrogen diffusivity $D=4 \times 10^{-8}\left(\mathrm{~cm}^{2} / \mathrm{sec}\right), \quad V H=2$ $\left(\mathrm{cm}^{3} / \mathrm{mol}\right)$, absolute temperature $T=300(\mathrm{~K})$, gas constant $R=1.98(\mathrm{cal} / \mathrm{mol} \mathrm{K})$ and $\gamma$ is neglected.

The process of hydrogen diffusion from initial stage onwards is shown in Fig. 9. Shading represents hydrogen concentration level which is normalized by the initial one charged 2 hours. With passage of time, those figures indicate that these processes have a clear tendency for diffusive hydrogen to gather toward the tip of notch at the imperfect root of thread where the stress concentration is higher than other regions.

\section{Comparison of Experiment and FE Analysis}

It was observed that $A E$ events occurred more frequently in long charged specimens. This observation is in good correspondence with the hydrogen accumulation behavior predicted by FE analysis. In other words, when hydrogen content is low by short charging, quantity of hydrogen dismissing into the air is considered to be so much that hydrogen content becomes relatively lower, and results in taking long time for diffusible hydrogen to reach around the higher stressed region. This may be one of reasons why the low charged specimen needed the time lag to occur AE signal.

It can be considered that phenomenon of branching is closely related to local hydrogen concentration near crack tip. This assumption is due to the analytical results indicated in Fig. 9, where diffusible hydrogen after rather long lapse time accumulates not just in front of notch but in both slant fields against the direction of notch. The direction of propagation of crack could be determined not only by the stressed field but also by the distribution of hydrogen because initiation of crack occurs much easily in the region of hydrogen embrittlement, which is caused by supplying the diffusible hydrogen form hydrogen rich regions. In this point, analytical result explains well this branching phenomenon. After area of free surface due to branching would nearly double, dismissing of hydrogen into the air would be promoted, hydrogen content would be lower, and consequently it would take a longer time for bolts to be fractured. It can be considered that the time to fracture must be affected by this increasing rate of free surface, and that whether there was branching or not is the reason why the test results were scattered in Fig. 5

The above instances prove these analytical results to be effective in explaining the experimental 
ones.

\section{Conclusion}

The hydrogen induced fracture in high-strength bolts under stress was investigated experimentally, and also the diffusional process of hydrogen in high-strength bolt was analyzed by FEM. This FE analysis, however, can't simulate the behavior of crack propagation process caused by hydrogen embrittlement because of the fixed division of finite elements. But the experimental and analytical results support the following conclusions:

(a) Cathodically charged F $13 \mathrm{~T}$ high strength bolts showed the phenomenon of delayed fracture induced by hydrogen, and this fracture is somewhat affected by hydrogen charged time and stressed level.

(b) Crack sensitivity depends much on hardenability due to heat treatment. Sufficient ductility and low crack sensitivity could resist the initiation of crack under hydrogen attacking.

(c) Mathematical development based on Fick's laws taking account of stress gradient and its discretization for numeric computational analysis were done. Hydrogen was diffused and accumulated in the slant fields against the direction of the mechanical saw notch where stress intensity is high, and its general behavior seems to agree with experimental results in view of branching phenomenon.

\section{Acknowledgments}

This research was funded by a Grant-in-Aid for Developmental Scientific Research from the Ministry of Education (1989-1991, Head investigator H. Shimomura). The authors are very grateful to Dr. B. Kato (emeritus prof. of Univ. of Tokyo), T. Haze (S-S engineering Co., Ltd.), Y. Sugihara and M. Kaga (Takigami Seiki Steel Construction Co., Ltd.) for their helpful cooperation, many valuable discussions and supplying the materials. These supports are gratefully acknowledged.

\section{References}

1) O.C. Zienkiewicz: "The Finite Element Method in Engineering Science", McGRAW-HILL, London (1971)

2) H. J. Maier, W. Popp and H. Kaesche : "A Method to Evaluate the Critical Hydrogen Concentration for Hydrogen-Induced Crack Propagation”, Acta Metal., Vol. 35, No.4, 1987

3) W. F. Savage et al. : "Hydrogen Induced Cold Cracking in HY-80 Steel Weldments", Welding Journal. Vol. 55 (1976), $368 \mathrm{~s}-376 \mathrm{~s}$

4) N. Yurioka : "Study on diffusion and accumulation of hydrogen in steel and its application for cold cracking in weld metal" Degree thesis in Kyoto Univ. (March 1981, in Japanese)

5) T. Araki : "Study on hydrogen embrittlement in steel" Degree thesis in Osaka Univ. (Aug. 1969, in Japanese).

6) C.E. Price and R. G. Norman : "A Comparison of Hydrogen and Mercury Embrittlement in AISI 4142 Steel”, Acta Metall. Vol. 35, No. 7, pp. 1639 1648, 1987

7) M. Arpaia, P. Pernice and A. Constantini : "A method to evaluate hydrogen embrittlement susceptibility of high-strength steel wires" Journal of Materials Science Letters, 9, (1990) pp. 268 269

8) K. Hoshino, R. Yamashita, T. Shinoda and H. Shimomura: "Study on hydrogen Induced Crack Propagation in High Strength Steel Welds", HYDROGEN and MATERIALS, 4th International Conference Proceedings, pp. 224 231, 1988. Beijing

9) H. Shimomura, T. Shinoda, K. Hoshino and R. Yamashita : Study on Delayed Crack Induced by Hydrogen in High Strength Steel Welds", Journal of Architectural Institute of Japan, Vol. 400 (1989) No. 6 pp. 85 89. (in Japanese)

10) H. Shimomura, T. Shinoda, K. Hoshino and R. Yamashita: "Analytical Study on Hydrogen Induced Cracking in HT-Steel Welds", Transaction of the Japan Welding Society, Vol. 21, No.2, pp.44 50, Oct., 1990

11) JSSC working group for delayed failure of high-strength bolt : "Atmospheric Weathering Test of High-Strength Bolted Joints (Continued Report 1, 2, 3, 4)”, JSSC journal, Vol. 7 (1971), Vol.9 (1973), Vol. 10 (1974), Vol. 11 (1975) (in Japanese)

12) H. Shimomura, T. Shinoda and T. Haze : "Hydrogen Induced Fracture of High Tension Bolts", 9 th International Conference on Offshore Mechanics and Arctic Engineering, proceedings Vol.3-B, pp.611 615, 1990. Houston, USA 


\section{和文要約}

\section{1. 序}

構造物の高層化・大スパン化に伴い，建築の分野でも SM 50 クラスを越える高性能鋼の使用も見在検討され つつある状況にある。一般に強度が高くなると降伏比が 高くなる傾向があり，高力ボルト接合によるボルト穴欠 損部周辺では応力集中により早期に降伏し，降伏比に よっては応力の再分配が十分行われず，ボルト接合部に 期待される耐力を十分発揮することができないことが予 期される。これを防ぐためには，ボルト穴による断面欠 損をできるだけ少なくすることが肝要で，そのためには 被接合部材の強度に合わせ高力ボルトの高強度化が必要 となる。しかし，それは過去にF 13 T クラスの高力ボ ルトを使用したほぼ全部の構造物で遅れ破壊を経験し， その結果使用が禁止された経緯があり, 多大な調査研究 がなされたにもかかわらず満足いく結果は得られなかっ た。それは, 高力ボルトは幾何学的な切欠 (ネジ部)に よる複雑な応力分布と応力集中を生じていること，また 䏛食環境による拡散性水素の侵入上応力にかかわる拡散 のメカニズムが明らかにされていなかった事にも起因し ている。したがって，本報告では応力勾配を考慮した水 素の拡散・集積過程を調查することを目的とする。

\section{2. 水素の忍力に依存する拡散過程と FEM への適用}

鋼中における水素の拡散過程を次のように定式化す る。物体内の任意な位置に図一 1 の微小 6 面体を考える。 拡散性水素の入出によって微小 6 面体の体積 $d v$ に蓄積 される水素量は, Fourier の法則を用いると, 微小時間 $d t$ で拡散係数が等方性であるとき濃度の時間変化は 2) 式で表せ得る。応力状態下にある鋼中を水素原子が抁散 する場合, 任意の点において単位時間に単位面積を通過 する拡散原子の流量ベクトル $J$ は，Fick の第一法則か ら 3）式のごとく表せ得る。また, Fick の第 2 法則から, 水素濃度の時間変化を水素濃度および応力の勾配で4） 式のごとく表すことができる。次に，この結果を $\mathrm{FE}$ 解析に適用することを考える。対象を有限な三角形一次 要素に分割し, ある任意な時刻 $t$ で要素内の濃度 $C$ を 節点濃度 $\phi$ で 5$)$ 式のように定める。この $[N]$ 自身を 重み関数として Galerkin 法を用いると6) 式となる。6) 式をGreen の定理を用いて展開し，さらにそれは解析 対象全体では7）式となる。これにより，空間的に解析 対象を離散化し、またCrank-Nicolson の差分式により 時間的にも離散化でき任意形状にも対応できる非定常問 題を解くことが可能となる。

\section{3. 遅れ破壊の実験的検証}

\section{1 遅れ破壊試験体}

実際に使用されている F $10 \mathrm{~T}$ 高力ボルトを通常用い られている熱処理のみにより F $13 \mathrm{~T}$ 高力ボルト試験体 を作成した。このボルトの特徵は, 焼入性向上のためボ ロンが添加されていることと熱間転造されていることで ある。また，不完全ネジ部には破壊を促進するために切 欠を挿入している。

\section{2 水素チャージ法}

拡散性水素を図一 2 に示す硫酸溶液による陰極チャー ジ法によりボルトに導入した。どの武験体も同一の電流 密度を保つため定電流電源により制御した。

\section{3 加力および $\mathrm{AE}$ 測定法法}

図一3に加力装置および $\mathrm{AE}$ 解析装置を示す。試験体 を水素チャージ後速やかに加力装置に組み込み, 所定の 軸力を導入した。AE センサーを常に同一箇所に設置し， 治具を介して計測した。

\section{4 破壊までの過程と実験結果}

加力装置に組み込まれた試験体における亀裂の発生と 伝播は, $\mathrm{AE}$ 解析装置により間接的に知ることができた。 この $\mathrm{AE}$ の発生状況（図一4）は, 導入軸力が高いほど, また, 水素チャージ時間の長いほど加力直後から活発に 発生し早く破断する傾向があった。

破断までの時間と導入軸力比そして水素チャージ時間 との関係を図一 5 に示す。この図から，破断に至る時間 が導入軸力と水素チャージ時間に深く関与していること が分かる。また, 水素チャージしていない F $13 \mathrm{~T}$ と 2 時間チャージした F $10 \mathrm{~T}$ とを載荷したが，共に $\mathrm{AE} の$ 発生もなく破断には至らなかった。このことは，F13 T ではこの水素チャージにより水素脆化を生じ亀裂の発生 と伝播を促したこと，および，F10 Tでは水素の存在 にもかかわらず亀裂が発生せず，割れ感受性が十分低い 事を示し, 同一素材でも熱処理により遅れ破壊特性が異 なることを示した。

\section{5 破面観察}

SEM により破断面を観察した。図一6からは，切欠 近傍で破壊は粒内・粒界を脆性的に進行したことが分か り，内部に行くにしたがって，擬脆性を呈するようにな り，さらには延性破面を呈するようになっていることが 観察される。また, 破面に垂直な断面のマクロ写真（図 一7) 加, 破面は粒界・粒内を進展している様子が分 かり,さらに亀裂先端部から亀裂が分岐していることも 示している。この分岐により自由表面が大幅に増加する こととなるため，㹡散性水素の空中への逸散は顕著にな 
り, 水素濃度が減少し, その結果, 破壊発生までの時間 が遅れることが予想され，図一5で結果がバラついてい たのもこの分肢の発生に関係していると思われる。

\section{4. 解析結果}

2. で展開した結果を高力ボルトに適用し解析した結 果が図-9で，水素の拉散状況を時間経過で示している。 時間の経過とともに水素が亀裂先端付近に集積している 様子が分かる。チャージ時間により水素量が少ないと外 部に拡散する量の方が相対的に多くなるので，経過と之 もに減少の度合いが高くなることを示しており，切欠近 傍に集積するためにはある一定量の水素が必要であるこ とが分かる。

\section{5. 実験結果と解析結果との比較}

実験で，水素チャージの少ない試験体が活発な $\mathrm{AE}$ の発生に時間を要すること, 破断までに長い時間を要し ている結果とが得られた。この事柄は, 解析結果で, 切 欠近傍までに水素が拡散 - 集積するのには時間を要し, またその時間は初期濃度に依存していることと対応して いる。また，長時間経過後の水素集積の状態で，亀裂の 先端より離れた位置に集積した結果を得た。この領域で は水素脆化するので亀裂の伝播がその方向に生じやすく
なることが予想されるが，亀裂が分岐しその方向へと進 んでいることが実験で観察された。

\section{6. 結 論}

陰極チャージを施した F $13 \mathrm{~T}$ 高力ボルトの遅れ破壊 試験と, 応力勾配を考慮した非定常拡散式を FE 解析 に適応し解析した結果より次の事がいえる。

(a) 陰極チャージのF 13 T ボルトは遅れ破壊し，破 壊は水素チャージ時間と導入軸力に依存する。

（b）割れ感受性は熱処理による焼入性に依存し，十 分な延性があれば水素が存在していても亀裂の発生に抵 抗する。

（c）応力勾配を考慮した式の展開をし，有限要素法 に適応を試みた結果，応力集中している部位に拡散性水 素は集積し，その解析結果は実験結果と対応している。

\section{謝辞}

本研究は文部省科学研究費（試験研究 (B) (1) 課題 番号 01850134 代表 下村波基）の助成を受けた。遂行に 当たり, 加藤 勉博士（東京大学名誉教授）には貴重な 示唆を, また，裭 忠夫氏 (SSエンジニヤリング), 杉原義則氏, 加賀 稔氏（瀧上精機工業）には多大な援 助を得たことに謝意を表する。 